\title{
Functional and radiological outcome after forearm plating in children and adolescent fracture
}

\author{
Paul Cremer, Audrey Angelliaume, Abdelfetah Lalioui, Gabriel Cellarier, Luke Harper, Yan Lefevre
}

From the Department of Pediatric Orthopaedics, Children hospital, Bordeaux, France

The literature on forearm overgrowth after plating in traumatic conditions is relatively poor though this technique can be useful when intra-medullary nailing is not sufficient in pediatric cases. The goal of this study was to assess a potential overgrowth after plating and identify impact on function.

We conducted a retrospective study of all pediatric patients who underwent open surgery of the radius and/or ulna diaphysis with internal fixation by plating, in our institution, between October 2013 and July 2019. At last follow-up, functional and radiological outcomes were compared between the operated and uninjured forearm. Range of motion (ROM) of the wrist and elbow, clinical scores, radial and ulnar length were measured. A positive bone length discrepancy of more than $2 \mathrm{~mm}$ was considered as an overgrowth. Were also studied the radio-ulnar index, radial inclination and radiocarpal angle.

Thirteen patients were included. The mean age was 12.1 years old ( \pm 3.0 years), they were plated on the radius ( 10 cases) or on the ulna ( 3 cases). Mean followup was 4.4 years $( \pm 1.8)$. In two cases, the plated bone (radius) was significantly longer than the uninjured one. There was no significant difference regarding radio-ulnar index, radial inclination and radiocarpal angle. The only statistically significant difference between the operated and uninjured forearm was the pronation/supination range, which was greater in the uninjured forearm (mean $160 \pm 48^{\circ}$ versus $175 \pm 49^{\circ}$, $\mathrm{p}=\mathbf{0 . 0 1}$ ).

This study confirms the good functional and radiological outcomes after plating even in a skeletally immature forearm.

Level of evidence : IV.
Keywords : forearm ; overgrowth ; plate ; children and adolescent.

\section{INTRODUCTION}

Intramedullary fixation of an unstable forearm fracture in skeletally immature patients is a safe and minimally invasive technique that allows early functional treatment with an excellent functional and cosmetic outcome $(1,2,3)$. However, in certain cases, adequate reduction is not possible with intramedullary nailing and plate fixation is the only alternative. However, the consequences on growth of forearm plating in children remain unclear. We tend to transpose our knowledge of the lower limb to the upper limb, and it is well known that plating

\footnotetext{
Paul Cremer, MD',

Audrey Angelliaume, $\mathrm{MD}^{2}$,

Abdelfetah Lalioui, $\mathrm{MD}^{2}$,

- Gabriel Cellarier, $\mathrm{MD}^{2}$,

- Luke Harper, $\mathrm{MD}^{2}$,

- Yan Lefevre, MD, $\mathrm{PhD}^{2}$.

${ }^{1}$ Hôpital privé Saint-Martin, Allée des Tulipes, 33600 Pessac, France.

${ }^{2} \mathrm{CHU}$ de Bordeaux, Place Amélie Raba-Léon, 33000

Bordeaux, France.

Correspondence : Dr Paul Cremer, Hôpital privé Saint-Martin, Allée des Tulipes, 33600 Pessac. Phone : +33556429214, Fax : +33556429214

E-mail : paul.cremer@hotmail.fr

- 2021, Acta Orthopædica Belgica.
} 
in femoral fractures in childhood cause subsequent overgrowth that needs to be anticipated in order to prevent limb length discrepancies of more than $1 \mathrm{~cm}$ which cause functional impairment $(4,5,6,7)$. The literature dealing with overgrowth in the upper limb is poor. However, this risk has to be evaluated because overgrowth of only one of the two forearm bones can lead to wrist and/or elbow biomechanic imbalance which can be responsible for pain and/or loss of function in adulthood $(8,9,10)$.

The aim of this study was to assess the radiological growth changes and functional outcomes in a group of patients with non-physeal forearm fractures or fracture sequelae treated by plating.

\section{MATERIAL AND METHOD}

We conducted a retrospective analysis of patients treated between October 2013 and July 2019. Our demographic data were collected from the electronic medical record of patients who underwent forearm plating (i.e. internal fixation by plate of the radius and/or ulna diaphysis) in our institution. All surgery was performed by members of a specialized paediatric orthopaedics team. Indications of plating were fractures or fracture sequelae. Exclusion criteria were physeal fractures, secondary fractures, congenital deformity surgery and patients older than 16 years old.

Radiological and functional evaluations were performed at latest follow-up.

All radiological and clinical data were collected by a paediatric orthopaedic surgeon.

Measurements of the operated and uninjured forearm were compared for each patient. A positive bone length discrepancy of more than $2 \mathrm{~mm}$ was considered as a significant overgrowth (11).

Clinical evaluation was performed as follows :

- Range of motion (ROM) of both elbow and wrist were recorded using a goniometer, in a standardized manner ${ }^{16}$, including extension, recurvatum, flexion of the elbow, flexion and extension of the wrist, and pronosupination of the forearm ;

- The strongest pain felt during the past three month was assessed using a visual analogic scale ;

- Quick-DASH score (Disability of arm, shoulder and hand), was used to quantify disabilities related

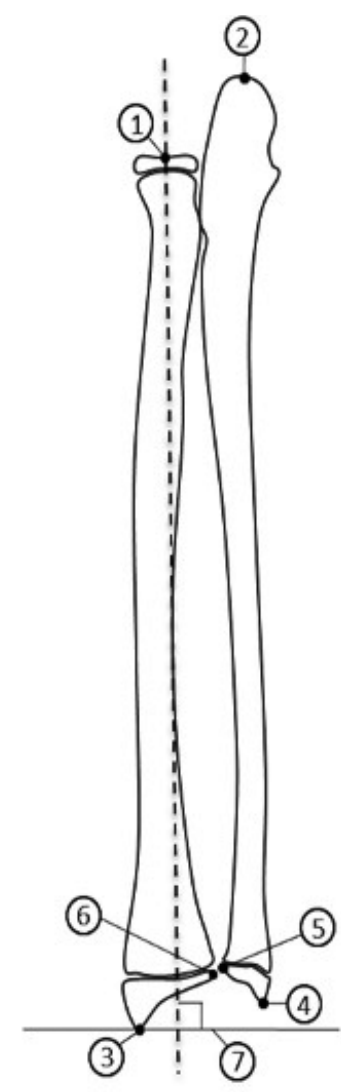

Figure 1. - Representation of radiological parameters measured. The length of the radius was measured between the center of the radial head (1) and the most distal point of the radius (3) in millimeter. The length of the ulna was measured between the center of the olecranon (2) and the most distal point of the ulna (4) in millimeter. The distal radio-ulnar index is measured in millimeter between the cortical margin of the distal ulna (5) and the cortical margin of the distal radius (6). The radial inclination, measured in degree, is the angle between a line connecting the radial styloid tip (3) and the cortical margin of the distal radius (6) and a second line perpendicular to the longitudinal axis of the radius (7). The radiocarpal angle, measured in degree, is the angle between a line connecting the tip of the radial styloid (3) to the tip of the ulnar styloid (4) and the same perpendicular line to the longitudinal axis of the radius (7).

to the upper extremity, with a score ranging from 0 points (no disability) to 100 points (maximum disability);

- Oswestry Elbow Score (OES), was used to quantify disabilities related to the elbow with a score ranging from 0 (maximum disability) to 48 (no disability) ; 
- MAYO Elbow Score (MES) and MAYO Wrist Score (MWS) were used to quantify disabilities related to the elbow and the wrist with a score ranging from 0 (maximum disability) to 100 (no disability).

Loss of motion was calculated as the difference between the operated forearm and the uninjured forearm.

Two specialized senior paediatric Orthopaedic Surgeons performed all surgery. The plate was positioned using an anterior Henry approach on the radius, or by classic posterior approach on the ulna. A T-Shaped plate was used for fractures close to radial physis ( 7 cases), in other cases, a Dynamic Compression Plate (DCP) was used (6 cases). An additional pin was put in the ulna in 2 cases. Patients were immobilized for 3 to 4 weeks in a full arm cast.

\section{Statistical analysis}

Statistical analysis was performed using SPSS software, version 20 (IBM, Armonk, New York, USA). Continuous variables were expressed as means and standard deviations (SD). Radiological parameters were compared between groups using a Student-t test, after verifying data was normally distributed. A $p$ value $<0.05$ was considered statistically significant.

\section{RESULTS}

Twenty-two patients underwent radial or ulnar plating. Out of these 22, 9 were lost to follow-up. Hence, thirteen patients were included, 7 males and 6 females. Mean age at surgery was 12.1 years old $( \pm 3.0$ years) and mean follow-up was 4.4 years ( \pm 1.8). Demographic characteristics of patients are summarized in table I.

The plated bone was the radius in 10 cases and the ulna in 3 cases. No patients were plated on both bones. The indication for plating the radius was: unstable distal third fracture with anterior displacement in 5 cases (primary plating in 3 cases, secondary displacement in two cases), posterior distal third fracture in 5 cases (primary plating in 3 cases, secondary displacement in two cases). The indication for plating the ulna was a Monteggia lesion involving the midshaft of the ulna in 3 cases (two primary plating, an plating for non-union after 6 month).

The demographic, and initial radiological characteristics of the patients lost to follow-up were not different from the study group.

\section{Radiological results (Tables II to V)}

Five out of 13 plated bones were longer than the uninjured one (Positive values in table II) and

Table I : demographic characteristics

\begin{tabular}{|c|c|c|c|c|c|c|c|c|c|c|}
\hline $\begin{array}{c}\text { Patient } \\
\text { No }\end{array}$ & $\begin{array}{c}\text { Sex/Age } \\
\text { (Years old) }\end{array}$ & $\begin{array}{l}\text { Injured } \\
\text { forearm }\end{array}$ & $\begin{array}{c}\text { Dominant } \\
\text { hand }\end{array}$ & $\begin{array}{c}\text { Plated } \\
\text { bone }\end{array}$ & Location & $\begin{array}{c}\text { Primary }(\mathrm{P}) / \\
\text { secondary }(\mathrm{S}) \\
\text { plating }\end{array}$ & Associated injury & $\begin{array}{c}\text { Type of } \\
\text { plate }\end{array}$ & $\begin{array}{l}N^{\circ} \text { of } \\
\text { holes* }\end{array}$ & $\begin{array}{c}\text { Plate } \\
\text { removal } \\
\text { (years) }\end{array}$ \\
\hline 1 & $\mathrm{~F} / 14.9$ & $\mathrm{~L}$ & No & Ulna & Midshaft & $\mathrm{P}$ & Radial head dislocation & DCP 3.5 & 7 & No \\
\hline 2 & $\mathrm{M} / 4.3$ & $\mathrm{~L}$ & Yes & Ulna & Midshaft & $\mathrm{S}$ & Radial head dislocation & DCP 3.5 & 4 & 0.4 \\
\hline 3 & $\mathrm{M} / 12.1$ & $\mathrm{R}$ & Yes & Radius & Distal 1/3 & $\mathrm{S}$ & 0 & T-Shaped & $5+3$ & 1.0 \\
\hline 4 & $\mathrm{M} / 13.0$ & $\mathrm{R}$ & Yes & Radius & Distal 1/3 & $\mathrm{P}$ & Ulna distal 1/3 F (pin) & DCP 3.5 & 5 & 0.6 \\
\hline 5 & $\mathrm{~F} / 14.5$ & $\mathrm{~L}$ & Yes & Ulna & Midshaft (NU) & $\mathrm{S}$ & Radial head dislocation & DCP 3.5 & 6 & No \\
\hline 6 & $\mathrm{~F} / 10.0$ & $\mathrm{~L}$ & No & Radius & Distal 1/3 & $\mathrm{S}$ & 0 & T-Shaped & $5+3$ & 0.9 \\
\hline 7 & $\mathrm{~F} / 10.5$ & $\mathrm{R}$ & Yes & Radius & Distal 1/3 & $\mathrm{P}$ & 0 & T-Shaped & $5+3$ & 0.6 \\
\hline 8 & $\mathrm{~F} / 10.5$ & $\mathrm{~L}$ & No & Radius & Distal 1/3 & $\mathrm{S}$ & 0 & DCP 3.5 & 6 & 0.8 \\
\hline 9 & $\mathrm{~F} / 11.7$ & $\mathrm{~L}$ & No & Radius & Distal 1/3 & $\mathrm{S}$ & 0 & T-Shaped & $5+3$ & 0.7 \\
\hline 10 & $\mathrm{M} / 11.8$ & $\mathrm{R}$ & Yes & Radius & Distal 1/3 & $\mathrm{P}$ & 0 & T-Shaped & $3+3$ & 0.1 \\
\hline 11 & $\mathrm{M} / 14.1$ & $\mathrm{R}$ & Yes & Radius & Distal 1/3 & $\mathrm{P}$ & Ulna distal 1/3 F (pin) & DCP 3.5 & 5 & 1.1 \\
\hline 12 & $\mathrm{M} / 14.6$ & $\mathrm{~L}$ & No & Radius & Distal 1/3 & $\mathrm{P}$ & 0 & T-Shaped & $5+3$ & 1.4 \\
\hline 13 & $\mathrm{M} / 15.2$ & $\mathrm{R}$ & No & Radius & Distal 1/3 & $\mathrm{P}$ & $\begin{array}{c}\text { Ulna distal } 1 / 3 \mathrm{~F} \text { (non- } \\
\text { op) }\end{array}$ & T-Shaped & $5+3$ & 1.1 \\
\hline
\end{tabular}

$\mathrm{L}:$ left ; R : Right ; NU : non-union; F : fracture ; * First number refering to metaphyso-diaphyseal holes, second number refering to epiphyseal holes 
Table II. - Comparison of bone lenght ( $\mathrm{mm}$ ) between operated and uninjured bone in each patient

\begin{tabular}{|c|c|c|c|c|}
\hline $\begin{array}{c}\text { Patient } \\
\text { No }\end{array}$ & $\begin{array}{c}\text { Bone } \\
\text { operated }\end{array}$ & $\begin{array}{c}\text { Lenght } \\
\text { operated } \\
\text { bone }\end{array}$ & $\begin{array}{c}\text { Lenght } \\
\text { uninjured } \\
\text { bone }\end{array}$ & $\begin{array}{c}\text { Lenght } \\
\text { difference } \\
\text { operated and } \\
\text { unjinjured } \\
\text { bone }\end{array}$ \\
\hline 1 & Ulna & 227 & 228 & -1 \\
\hline 2 & Ulna & 157,9 & 158,4 & $-0,5$ \\
\hline 3 & Radius & 273,3 & 272,1 & 1,2 \\
\hline 4 & Radius & 270,7 & 272,6 & $-1,9$ \\
\hline 5 & Ulna & 263,5 & 269,1 & $-5,6$ \\
\hline 6 & Radius & 230,8 & 235,2 & $-4,4$ \\
\hline 7 & Radius & 228,4 & 226,8 & 1,6 \\
\hline 8 & Radius & 240,7 & 229,6 & 11,1 \\
\hline 9 & Radius & 244,2 & 240,7 & 3,5 \\
\hline 10 & Radius & 241 & 240 & 1 \\
\hline 11 & Radius & 269,2 & 270,3 & $-1,1$ \\
\hline 12 & Radius & 249 & 252 & -3 \\
\hline 13 & Radius & 244 & 245 & -1 \\
\hline
\end{tabular}

Table III. - Comparison of radioulnar index (mm) between operated and uninjured bone in each patient

\begin{tabular}{|c|c|c|c|c|}
\hline $\begin{array}{c}\text { Patient } \\
\text { No }\end{array}$ & $\begin{array}{l}\text { Operated } \\
\text { bone }\end{array}$ & $\begin{array}{c}\text { Uninjured } \\
\text { bone }\end{array}$ & $\begin{array}{c}\text { Difference } \\
\text { between } \\
\text { operated and } \\
\text { uninjured } \\
\text { bone }\end{array}$ & $\mathbf{p}$ \\
\hline 1 & 1,9 & 2,1 & $-0,2$ & \multirow{13}{*}{$\mathrm{p}=0.1$} \\
\hline 2 & 5,5 & 4,6 & 0,9 & \\
\hline 3 & 7,8 & 6,8 & 1 & \\
\hline 4 & 2,3 & 2,2 & 0,1 & \\
\hline 5 & 3,5 & 3,2 & 0,3 & \\
\hline 6 & 1,7 & 2 & $-0,3$ & \\
\hline 7 & 2 & 1,4 & 0,6 & \\
\hline 8 & 5,8 & 1 & 4,8 & \\
\hline 9 & 6,2 & 2,5 & 3,7 & \\
\hline 10 & 2,4 & 2,8 & $-0,4$ & \\
\hline 11 & 2,4 & 1,5 & 0,9 & \\
\hline 12 & 3 & 1 & 2 & \\
\hline 13 & 3,3 & 2,4 & 0,9 & \\
\hline
\end{tabular}

this bone discrepancy was significant $(>2 \mathrm{~mm})$ in 2 patients. In both cases this concerned the radius, in no cases was the operated ulna longer than the uninjured one.

Comparing the operated and uninjured forearm in each patient, there was no significant difference regarding radio-ulnar index $(\mathrm{p}=0.1)$ (Table III),
Table IV. - Comparison of radial inclination (angle in ${ }^{\circ}$ ) between operated and uninjured bone in each patient

\begin{tabular}{|c|c|c|c|c|}
\hline $\begin{array}{c}\text { Patient } \\
\text { No }\end{array}$ & $\begin{array}{l}\text { Operated } \\
\text { bone }\end{array}$ & $\begin{array}{c}\text { Uninjured } \\
\text { bone }\end{array}$ & $\begin{array}{l}\text { Difference } \\
\text { between } \\
\text { operated and } \\
\text { uninjured } \\
\text { bone }\end{array}$ & p \\
\hline 1 & 32 & 28 & 4 & \multirow{13}{*}{$\mathrm{p}=0.4$} \\
\hline 2 & 24 & 23 & 1 & \\
\hline 3 & 22 & 20 & 2 & \\
\hline 4 & 27 & 32 & -5 & \\
\hline 5 & 24 & 26 & -2 & \\
\hline 6 & 23 & 23 & 0 & \\
\hline 7 & 30 & 25 & 5 & \\
\hline 8 & 28 & 28 & 0 & \\
\hline 9 & 31 & 24 & 7 & \\
\hline 10 & 28 & 29 & -1 & \\
\hline 11 & 31 & 33 & -2 & \\
\hline 12 & 24 & 33 & -9 & \\
\hline 13 & 29 & 49 & -10 & \\
\hline
\end{tabular}

Table V. - Comparison of radiocarpal $\left(^{\circ}\right)$ between operated and uninjured bone in each patient.

\begin{tabular}{|c|c|c|c|c|}
\hline $\begin{array}{c}\text { Patient } \\
\text { No }\end{array}$ & $\begin{array}{l}\text { Operated } \\
\text { bone }\end{array}$ & $\begin{array}{c}\text { Uninjured } \\
\text { bone }\end{array}$ & $\begin{array}{c}\text { Difference } \\
\text { between } \\
\text { operated and } \\
\text { uninjured } \\
\text { bone }\end{array}$ & p \\
\hline 1 & 20 & 18 & 2 & \multirow{13}{*}{$\mathrm{p}=0.5$} \\
\hline 2 & 23 & 19 & 4 & \\
\hline 3 & 24 & 24 & 0 & \\
\hline 4 & 21 & 26 & -5 & \\
\hline 5 & 19 & 13 & 6 & \\
\hline 6 & 14 & 12 & 2 & \\
\hline 7 & 19 & 9 & 10 & \\
\hline 8 & 68 & 49 & 19 & \\
\hline 9 & 28 & 18 & 10 & \\
\hline 10 & 17 & 16 & 1 & \\
\hline 11 & 27 & 25 & 2 & \\
\hline 12 & 15 & 26 & -11 & \\
\hline 13 & 10 & 4 & 6 & \\
\hline
\end{tabular}

radial inclination $(\mathrm{p}=0.4)$ (Table IV) nor radiocarpal angle $(\mathrm{p}=0.5)$ (Table V).

\section{Functional results (tables VI and VII)}

At follow-up, the mean maximum pain felt during the last three month was 1/10 $( \pm 1.8)$. Elbow 
Table VI. - Comparison of range of motion $\left(^{\circ}\right)$ between operated and uninjured forearm in each patient

\begin{tabular}{|c|c|c|c|c|c|c|c|c|c|c|c|c|}
\hline \multirow{3}{*}{$\begin{array}{l}\text { Patient } \\
\text { No }\end{array}$} & \multicolumn{3}{|c|}{ Elbow } & \multicolumn{6}{|c|}{ Wrist } & \multirow{2}{*}{\multicolumn{3}{|c|}{ Pronation/Supination }} \\
\hline & \multicolumn{3}{|c|}{$\begin{array}{c}\text { Flessum/Recurvatum/ } \\
\text { Extension }\end{array}$} & \multicolumn{3}{|c|}{ Flexion/Extension } & \multicolumn{3}{|c|}{ Ulnar/Radial inclination } & & & \\
\hline & $\begin{array}{c}\text { Operated } \\
\text { bone }\end{array}$ & $\begin{array}{c}\text { Uninjured } \\
\text { bone }\end{array}$ & $\mathrm{p}$ & $\begin{array}{l}\text { Operated } \\
\text { bone }\end{array}$ & $\begin{array}{l}\text { Uninjured } \\
\text { bone }\end{array}$ & $\mathrm{p}$ & $\begin{array}{l}\text { Operated } \\
\text { bone }\end{array}$ & $\begin{array}{c}\text { Uninjured } \\
\text { bone }\end{array}$ & $\mathrm{p}$ & $\begin{array}{l}\text { Operated } \\
\text { bone }\end{array}$ & $\begin{array}{c}\text { Uninjured } \\
\text { bone }\end{array}$ & $\mathrm{p}$ \\
\hline 1 & $12 / 0 / 128$ & $10 / 0 / 130$ & \multirow{13}{*}{$\begin{array}{c}0.13 / \\
0.21 / \\
0.78\end{array}$} & $62 / 70$ & $66 / 62$ & \multirow{13}{*}{$\begin{array}{l}0.23 / \\
0.76\end{array}$} & $35 / 10$ & $44 / 20$ & \multirow{13}{*}{$\begin{array}{c}0.79 / \\
0.25\end{array}$} & 135 & 180 & \multirow{13}{*}{0.01} \\
\hline 2 & $5 / 0 / 128$ & $5 / 0 / 138$ & & $70 / 85$ & $70 / 85$ & & $45 / 27$ & $43 / 25$ & & 90 & 180 & \\
\hline 3 & $0 / 0 / 135$ & $5 / 0 / 148$ & & $80 / 66$ & $76 / 66$ & & $30 / 7$ & $34 / 9$ & & 135 & 170 & \\
\hline 4 & $8 / 0 / 126$ & $12 / 0 / 134$ & & $60 / 66$ & $92 / 83$ & & $40 / 30$ & $45 / 34$ & & 140 & 170 & \\
\hline 5 & $2 / 0 / 120$ & $4 / 0 / 140$ & & $64 / 70$ & $60 / 60$ & & $22 / 10$ & $32 / 16$ & & 145 & 170 & \\
\hline 6 & $14 / 0 / 136$ & $18 / 0 / 128$ & & $45 / 83$ & $58 / 85$ & & $48 / 38$ & $45 / 40$ & & 180 & 180 & \\
\hline 7 & $4 / 0 / 134$ & $12 / 0 / 138$ & & $36 / 48$ & $52 / 55$ & & $57 / 30$ & $58 / 32$ & & 160 & 160 & \\
\hline 8 & $0 / 0 / 160$ & $0 / 0 / 160$ & & $70 / 80$ & $73 / 90$ & & $60 / 40$ & $65 / 35$ & & 180 & 180 & \\
\hline 9 & $8 / 0 / 140$ & $6 / 0 / 130$ & & $58 / 68$ & $80 / 75$ & & $30 / 34$ & $30 / 36$ & & 160 & 180 & \\
\hline 10 & $0 / 0 / 160$ & $0 / 0 / 160$ & & $86 / 76$ & $85 / 72$ & & $35 / 42$ & $37 / 40$ & & 180 & 180 & \\
\hline 11 & $0 / 5 / 136$ & $6 / 0 / 146$ & & $48 / 65$ & $56 / 62$ & & $30 / 25$ & $34 / 30$ & & 160 & 170 & \\
\hline 12 & $0 / 0 / 160$ & $0 / 0 / 160$ & & $67 / 80$ & $69 / 80$ & & $54 / 26$ & $34 / 39$ & & 180 & 180 & \\
\hline 13 & $0 / 0 / 160$ & $0 / 10 / 130$ & & $90 / 90$ & $90 / 90$ & & $35 / 10$ & $35 / 40$ & & 165 & 180 & \\
\hline
\end{tabular}

Table VII. - Functional score

\begin{tabular}{|c|c|c|c|c|}
\hline $\begin{array}{c}\text { Patient } \\
\text { No }\end{array}$ & $\begin{array}{c}\text { Quick- } \\
\text { DASH }\end{array}$ & $\begin{array}{c}\text { Owestry } \\
\text { Elbow Score }\end{array}$ & $\begin{array}{c}\text { Mayo } \\
\text { Elbow } \\
\text { Score }\end{array}$ & $\begin{array}{c}\text { Mayo } \\
\text { Wrist } \\
\text { Score }\end{array}$ \\
\hline 1 & 2,3 & 45 & 85 & 100 \\
\hline 2 & 2,3 & 48 & 100 & 100 \\
\hline 3 & 2,3 & 45 & 100 & 90 \\
\hline 4 & 0 & 48 & 100 & 100 \\
\hline 5 & 6,8 & 42 & 85 & 100 \\
\hline 6 & 0 & 48 & 100 & 100 \\
\hline 7 & 0 & 48 & 100 & 100 \\
\hline 8 & 0 & 48 & 100 & 100 \\
\hline 9 & 2,3 & 48 & 100 & 100 \\
\hline 10 & 0 & 48 & 100 & 100 \\
\hline 11 & 2,3 & 48 & 100 & 100 \\
\hline 12 & 0 & 48 & 100 & 95 \\
\hline 13 & 0 & 48 & 100 & 100 \\
\hline Mean & 1.3 & 47 & 97 & 99 \\
\hline $\begin{array}{c}\text { Standard } \\
\text { deviation }\end{array}$ & 2.0 & 13 & 29 & 29 \\
\hline & & & & \\
\hline
\end{tabular}

and wrist ROM are summarized in table VI. The only statistically significant difference between the operated and uninjured forearm is pronosupination, which was greater in the uninjured forearm (mean $160 \pm 48^{\circ}$ versus $175 \pm 49^{\circ}, \mathrm{p}=0.01$ ).

Functional scores at follow-up were very good (Table VII). Ten out of the 13 patients presented a maximum OES score. Eleven out of 13 patients had a maximum MES and MWS score.

It was not possible to compare the functional results of patients with and without overgrowth because there were too few of them.

\section{DISCUSSION}

This study presents the radiological and clinical outcome of forearm fractures or fracture sequelae treated by open reduction and internal fixation by plate. Regarding the ulna fractures, all 3 were associated with radial head dislocation (Monteggia lesion). This may be important regarding the functional outcome but we don't think that the radial head dislocation may alter radial growth. Thus we decided to include them to study a potential ulnar overgrowth after plating.

We report only 2 cases of significant overgrowth in our series of 13 patients. The two occurred after radius plating, in girls aged 10 and 11.5 years old. Surgical indications were secondary displacement of distal radius fractures with anterior displacement. These two patients had similar ROM in the operated and uninjured forearms and their functional scores were very good (maximum scores of OES, MES, MWS, Quick-DASH 0 and 2.3). The patient with the greatest overgrowth (Figure 2) showed 


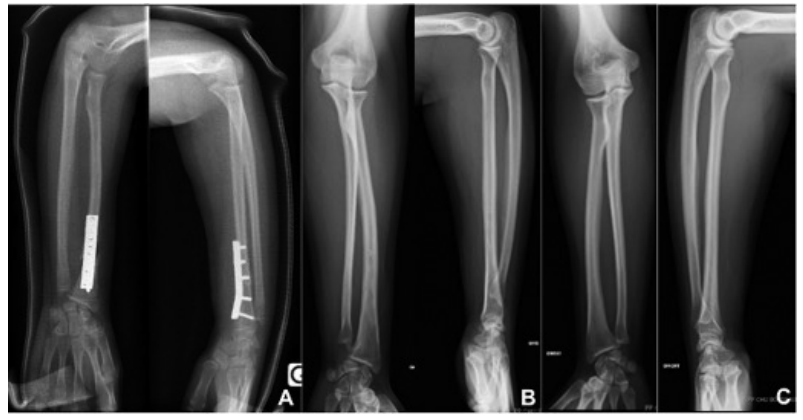

Figure 2. - X-ray of patient with an overgrowth of $11 \mathrm{~mm}$. A : Postoperative $x$-ray, note that radio-ulnar index is respected. B : Operated forearm at 8 years of follow-up, modification of radio-ulnar index measured at $6 \mathrm{~mm}$. C : Uninjured forearm, radio-ulnar index measured at $1 \mathrm{~mm}$.

abnormal radiological parameters (increased radioulnar index) but no functional impairment at 8 years follow-up (maximum score in each functional test and no significant difference between operated and uninjured forearm ROM). These results are consistent with the literature, as in the series by Nielsen and Simonsen (12) where they report no disturbance of functional results in a series of 27 patients with a mean overgrowth of $2.4 \mathrm{~mm}$ after forearm plating.

There is a case report of clinically symptomatic overgrowth of the radius after plating of the distal 1/3 in a 12 years old patient (13). The patient suffered two fractures at the exact same place within 4 months. He was treated conservatively the first time, and surgically with plating of the radius the second time. Three years postoperatively, the patient noticed pain in his left wrist. ROM of wrist was complete in flexion, extension, supination, pronation and ulnar deviation. He exhibited maximum radial deviation in neutral position, the ulna was subluxed in supination and the distal radioulnar joint was hypermobile. In this case, overgrowth was angular and responsible for palmar subluxation of the distal ulna and instability of the distal radioulnar joint. Functional impairment might well have been more connected to angular deformity than to overgrowth.

Only few published studies raise the issue of overgrowth, and the originality of our series is that we combine a comparative radiological study of both forearms with a clinical functional assessment. In the paper by Nielsen and Simonsen (12), X-rays of 24 fractures demonstrated overgrowth, 5 plated bones were shorter and 14 presented no overgrowth. In 10 patients with internal fixation by plating of both forearm bones, there was a mean difference of length of $4 \mathrm{~mm}$ between both bones. In a study including 32 patients, Cai et al (14) compared 19 patients undergoing a hybrid fixation using open reduction and plating of the ulna and 13 patients treated with dual plating fixation. They reported no overgrowth in either method, and especially no modification of the radio-ulnar index in the group with hybrid fixation.

Carsi et al (11), in a series of 119 nonphyseal forearm fracture treated conservatively reported $27 \%$ of radius overgrowth and $24 \%$ of ulnar overgrowth at 5 years post-injury. They showed that proximal and middle third fractures of the radius were associated with overgrowth whereas distal third fractures were associated with growth arrest $(p<0.05)$. We did not find these results, since the overgrowths we observed were both subsequent to distal third fractures which were plated, whereas Carsi et al studied conservative treatments.

To sum-up, there are papers reporting some cases of overgrowth after plating (current study) $(12,13)$, and others reporting no overgrowth after plating $(1,15)$. There are also studies presenting overgrowth after conservative treatment $(11,16)$ and others found length discrepancy between the two bones when both were plated (14). Thus, it is rather difficult to draw firm conclusions. Age, sex and type of fracture do not seem to influence the length difference $(12,16)$. Carsi et al (11) reported that dominant forearms showed positive values of length differences whereas nondominant forearms showed negative values. And this remained true when considering dominance using multiple regression analysis.

Functional outcomes are satisfying in our series, as they seem to be in the literature, even if there is overgrowth $(11,12,14)$. In our patients, supination/ pronation was the only ROM significantly worse on the operated forearm in comparison with the uninjured forearm. No patient but one complained about loss of supination/pronation (patient 2, Monteggia fracture, ulna plated). Patient's 8 and 9, on which we observed an overgrowth, supination/ pronation ROM was good and clinical scores were 
excellent (Table VI and VII). This result is consistent with the literature, as pronation/supination was the first ROM diminished after forearm fracture regardless of the treatment method $(1,12,15,17)$.

The current study obviously has limitations. The retrospective design of the study contributes to the high number of patients lost to follow-up and the relatively small number of patients included. Its strengths however is the follow-up, as we believe the $4.4( \pm 1.8)$ years average follow-up allows us to identify all cases of overgrowth since it occurs during the 18 months following injury $(18,19)$, and this study is the first to combine clinical and radiological results using the uninjured forearm as a control.

To conclude, radiological and functional outcomes after forearm plating in children are satisfying.

\section{REFERENCES}

1. Fernandez FF, Egenolf M, Carsten C, Holz F, Schneider S, Wentzensen A. Unstable diaphyseal fractures of both bones of the forearm in children: plate fixation versus intramedullary nailing. Injury. 2005 Oct ; 36(10) : 1210-6.

2. Westacott DJ, Jordan RW, Cooke SJ. Functional outcome following intramedullary nailing or plate and screw fixation of paediatric diaphyseal forearm fractures: a systematic review. J. Child Orthop. 2012 Mar ; 6(1) : 75-80.

3. Patel A, Li L, Anand A. Systematic review : functional outcomes and complications of intramedullary nailing versus plate fixation for both-bone diaphyseal forearm fractures in children. Injury. $2014 \mathrm{Aug}$; 45(8) : 1135-43.

4. Edvardsen P, Syversen SM. Overgrowth of the femur after fracture of the shaft in childhood. J. Bone Joint Surg. Br. 1976 Aug ; 58(3) : 339-42.

5. Hariga H, Mousny M, Docquier P-L. Leg length discrepancy following femoral shaft fracture in children : clinical considerations and recommendations. Acta Orthop. Belg. 2011 Dec ; 77(6) : 782-7.

6. Park S-S, Noh H, Kam M. Risk factors for overgrowth after flexible intramedullary nailing for fractures of the femoral shaft in children. Bone Jt. J. 2013 Feb ; 95-B(2) : 254-8.
7. Clement DA, Colton CL. Overgrowth of the femur after fracture in childhood. An increased effect in boys. J. Bone Joint Surg. Br. 1986 Aug ; 68(4) : 534-6.

8. Tarr RR, Garfinkel AI, Sarmiento A. The effects of angular and rotational deformities of both bones of the forearm. An in vitro study. J. Bone Joint Surg. Am. 1984 Jan ; 66(1) : 65-70.

9. Weinberg A-M, Kasten P, Castellani C, Jablonski M, Hofmann U, Reilmann H. Which Axial Deviation Results in Limitations of Pro- and Supination Following Diaphyseal Lower Arm Fracture in Childhood? : Eur. J. Trauma. 2001 Dec ; 27(6) : 309-16.

10. Colaris JW, Allema JH, Reijman M, de Vries MR, Ulas Biter L, Bloem RM, et al. Which factors affect limitation of pronation/supination after forearm fractures in children? A prospective multicentre study. Injury. 2014 Apr ; 45(4) : 696-700.

11. Carsi B, Abril JC, Epeldegui T. Longitudinal growth after nonphyseal forearm fractures. J. Pediatr. Orthop. 2003 Apr ; 23(2) : 203-7.

12. Nielsen $\mathbf{A B}$, Simonsen $\mathbf{O}$. Displaced forearm fractures in children treated with AO plates. Injury. 1984 May ; 15(6) : 393-6.

13. Williams AA, Szabo RM. Radial Overgrowth and Deformity after Metaphyseal Fracture Fixation in a Child. Clin. Orthop. 2005 Jun ; NA ; (435) : 258-62.

14. Cai L, Wang J, Du S, Zhu S, Wang T, Lu D, et al. Comparison of Hybrid Fixation to Dual Plating for BothBone Forearm Fractures in Older Children. Am. J. Ther. 2016 Dec ; 23(6) : e1391-6.

15. Zhao L, Wang B, Bai X, Liu Z, Gao H, Li Y. Plate Fixation Versus Intramedullary Nailing for Both-Bone Forearm Fractures: A Meta-analysis of Randomized Controlled Trials and Cohort Studies. World J. Surg. 2017 Mar ; 41(3) : 722-33.

16. de Pablos J, Franzreb M, Barrios C. Longitudinal growth pattern of the radius after forearm fractures conservatively treated in children. J. Pediatr. Orthop. 1994 Aug ; 14(4) : 492-5.

17. Nenopoulos SP, Beslikas TA, Gigis JP. Long-term followup of combined fractures of the proximal radius and ulna during childhood : J. Pediatr. Orthop. B. 2009 Sep ; 18(5) : 252-60.

18. Reynolds DA. Growth changes in fractured long-bones : a study of 126 children. J. Bone Joint Surg. Br. 1981 Feb ; 63-B(1) : 83-8.

19. Shapiro F. Fractures of the femoral shaft in children. The overgrowth phenomenon. Acta Orthop. Scand. 1981 Dec ; 52(6) : 649-55. 